\title{
Impact of Religion/Spirituality on Health: What are the Evidences?
}

\section{Hena Jawaid*}

Psychiatry Unit, Aga Khan University Hospital, Karachi, Pakistan

*Corresponding author: Hena Jawaid, Chief Resident, Psychiatry Unit, Aga Khan University Hospital, Karachi, Pakistan, Tel: 923337927925; E-mail: henajawaid000@hotmail.com

Received Date: August 1, 2014, Accepted Date: September 23, 2014, Published Date: September 30, 2014

Copyright: $\odot 2014$, Hena J, This is an open-access article distributed under the terms of the Creative Commons Attribution License, which permits unrestricted use, distribution, and reproduction in any medium, provided the original author and source are credited.

\begin{abstract}
From advancement of mechanistic view of human body to shifting paradigm of evaluation in medicine, world has changed a lot in last two decades in terms of visualizing a person as One Whole Being. Recently many studies have evolved with a question of spirituality benefits on health. Articles largely concentrated on reduction of physical as well as mental symptoms through association with religious practices. On the other hand, some argue on its association considering error in research designs and bias in studies which have linked positive correlation between religion and health. This review article has considered both accounts of objections as well as neutral studies along with recent developments, which is basically integration of spirituality into medical curriculum. Why it is now gaining attention? Why in need of most of the distressed patients? How religion affects coping and perception of a person and help in crisis? Current approach is critically analyzed for further studies to establish ambiguity in many areas and discussed benefits as how health system can be improved through incorporation of spiritual aspect into health assessment.
\end{abstract}

\section{Health of mind and body}

Ancient Greek period focused body and mind using two approaches (1) the materialist; stating matter, or brain (2) the personalist; central in the person is the core called the soul, self, or ego states i.e., thought and emotion.

In most cultures of the world, both in ancient and in modern times care for the soul and body were integrated aspect of any culture. Those who were assigned to the care of people in the culture attended to both their physical and spiritual needs; there were no dichotomy between the needs of the body and the needs of the spirit. In many ancient cultures, the shaman was a religious figure as well as healer also in Christianity; Jesus was a healer of body and spirit. In last few decades, this separation has developed that resulted in religiosity that is solely dedicated for spiritual concerns, while physicians and scientists, to the physical one $[1,2]$.

Rene Descartes, a seventeenth-century philosopher who believed in mechanical laws and gave little or no concern to meaning. His ideologies are dealing with rupture of body and spirit, the healing picture which came to surface contained detached body and soul [3].

Due to rapid succession of discoveries in last couple of decades and progression of neuro-anatomy, neurophysiology and micro-biology, the brain and behavior discussions got a new vision; vision of machine, science and objectivity. By the time, old belief of spiritual highness and intellectual well-being were overshadowed by molecular sciences [Freud et al., 1895].

The authors of the Persuasion and healing holds that effort should be made to steer between doubt and the acceptance. Too much "skepticism" dependent upon standardized scientific methods can miss real phenomena, while too enthusiastic "willingness" to accept every subjective finding may lead to false results. Remen, who has developed Commonweal Retreats for people with cancer, described it well: "Helping, fixing, and serving represent three different ways of seeing life. When you help, you see life as weak. When you fix, you see life as broken. When you serve, you see life as whole. Fixing and helping may be the work of the ego, and service the work of the soul." $[4,5]$.

Every person has his/her own life stories, relationships, meanings and purpose of life, simply treating a medical diagnosis is not more than approaching a patient with materialist approach only [6] or in another word devaluing him/her from existential connection with others.

\section{Significance of religion/spirituality in life}

Religion deals with external functions and apparent code of conduct while spirituality concerns with esoteric dimensions of personality like finding serenity with nature or with surrounding and with God, also to explore out meaning and motives of life. The main features of spirituality as defined by Martsolf and Mickley [7] are meaning, connecting, transcendence and value. Similarly, William James [8] has also distinguished an experiential religion from an Institutional religion with intrinsic and extrinsic meaning respectively.

Simpson and Weiner [9], in the Oxford English Dictionary, offers two related themes.First, spirituality refers to life's most vital issues and concerns (e.g., the term spiritus in Latin means "the breath," most vital to life). Second, spirituality is seen as subjective features of life including the senses, such as sight and hearing. The Association of American Medical Colleges defines spirituality as a broad one: "Spirituality is recognized as a factor that contributes to health in many persons. The concept of spirituality is found in all cultures and societies. It is expressed in an individual's search for ultimate meaning". Anandarajah $[10,11]$ explained that important aspects of spirituality are love and peace that individuals derive from their relationships, nature and God. Spirituality can be described as latent constructs, as it cannot be observed directly but can be inferred from some of their elements [12]. 
Page 2 of 5

More than an objective definition, the concept of health has emerged ahead of biological functioning, influenced by cultural, social, and philosophical factors, including purpose in life and the quality of healthy personal relationships [13]. Although researches helped out a lot in sorting out spirituality role but it will take many more years to understand different aspects of spirituality to unfold some of medicine's greatest mysteries

\section{Evidence based association between spirituality and health}

When a person gets ill, he/she experiences stress over the changes in life then eventually looks for evident reasons or solutions for cure, and when the medical system fails to do so, then patient begins to look towards spirituality for healing in other way. Those who were not religious previously may turn to religion for comfort and acquired it as a new method of coping.

In 1974, Benson found that 10 to 20 minutes of meditation twice a day leads to decreased metabolism, decreased heart rate, decreased respiratory rate, and slower brain waves, the practice was beneficial for the treatment of chronic pain, insomnia, anxiety, hostility, depression, premenstrual syndrome, and infertility and was a useful adjunct to treatment for patients with cancer or HIV. The personal beliefs influence illness prevention, coping, recovery, and illness experience. Patients showed less psychological distress if they connect with God in hope for healing and relaxation, most of them report strength and comfort from their spiritual beliefs $[14,15]$.

\section{Positive outcomes}

A number of studies suggest reduced mortality for population who are frequently attending religious services compared to those who do not attend. The 12-step program Alcoholics Anonymous lists as one of the 12 steps as: "[we] came to believe that a power greater than ourselves could restore us to sanity" [16-18]. With further exploration it was found out that meditation is a good therapy for chronic conditions such as headaches, anxiety, depression, premenstrual syndrome, AIDS, and cancer. Benson's relaxation response elicited by a simple two-step procedure:

(a) Repeating a word or muscular activity

(b) Passively ignore any other obtrusive thoughts and returning to the repetition.

In 2008, Pargament investigated factors such as heart disease, dyslipidemia, hypertension, cancer and mortality have inverse relationship with religious behaviors. Across every health domain, every predominant religion and spirituality has its own measure of involvement, most notably, frequency of church attendance. Growing literature suggested strong coping in adolescent religious patients with medical conditions such as arthritis, diabetes, renal disease, cancer, cardiovascular disease, pulmonary disease, HIV/AIDS, cystic fibrosis, sickle cell anemia, amyotrophic lateral sclerosis, chronic pain, and terminal illnesses. In 1995, McCullough reviewed effect of religious behavior on neuro-immunologic, cardiovascular, and musculoskeletal changes. Other than these findings better immune function, lower death rates from cancer, better cardiac outcomes, lower blood pressure, lower cholesterol and less cigarette smoking, more exercise and better sleep was also marked in his book called "Handbook of religion and health" [19-23].

\section{Local findings}

The study by Qidwai et al. [24] was conducted in 2008 represented majority of the respondents (95.8\%) believed -prayers can heal. Three fourth $(75.3 \%)$ of them believe that prayers can curtail the duration of disease, $49 \%$ believed that illness does not prolong by prayers. It is equally important to realize that $160(40 \%)$ participants believed that prayers can prolong life. Methods used for healing by study participants, include: reciting verses from Holy Quran, blowing them on water and then drinking it and wearing of taweez (amulet) which is thought to speed up healing process.

\section{Psychological/mental health associations with spirituality}

Emmons (1999) observed that through stressful hours, religious adherence can provide stability, support, and direction to find an ultimate purpose and meaning in life. Spirituality orientations can shape efficient methods for coping that linked to better mental health $[25,26]$. In a study by Baetz et al. [27], religious attitudes were attributed to greater life satisfaction. Increased satisfaction was predicted by Worship-attendance frequency. Increased Alcohol use was inversely proportional to Worship-attendance frequency. Spiritual well-being is positively associated with quality of life, decreased episodes of depression, anxiety and cognitive avoidance [28].

\section{Negative outcomes}

Whether religious beliefs and practices are actually effective in helping people to cope? It was a complete "No" by 20th century professionals. Religion regarded as irrelevant to health, even extended to become a cause of neurosis [29,30]. Rosenstiel and Keefe found that spirituality has been found to be related to higher pain levels. Religious struggles have been related with a number of indicators of psychological distress, including anxiety, depression, negative mood, poorer quality of life, panic disorder, and suicidality (Exline et al., Hays, Meador, Branch, \& George, Krause, Ingersoll- Dayton, Ellison, \&Wulff, Pargament et al., Pargament, Smith, Koenig, \& Perez, Pargament, Zinnbauer, et al.,; Trenholm, Trent, \& Compton) [31-37].

When patients are hospitalized they often ask the question, "why me?", as prayers for healing and relief go unanswered, they ask "Is God punishing me for my sins"? Patients usually get "stuck" in these spiritual struggles and without help are unable to resolve them on their own. In turn they avoid spiritual beliefs to rely on that might otherwise give them comfort and hope.

\section{No association}

In 1872, Galton published a retrospective study of the effects of prayer on the health of clergy. Galton concluded that there were no benefits also cited an earlier study which concluded that the many prayers offered for the good health of British monarchs afforded them no increased longevity. In other studies, spirituality was shown to be unrelated to pain severity, pain distress, and the disruption of activities by pain [38]. 
Citation: Hena Jawaid (2014) Impact of Religion/Spirituality on Health: What are the Evidences?. J Psychiatry 17: 1000164. doi: $10.4172 / 1994-8220.1000164$

Page 3 of 5

\section{Integrating spiritual training in medical course}

\section{Why spirituality was ignored?}

Psychologists and other social scientists have generally kept their distance from religion and spirituality. Few professional training programs in psychology address religious and spiritual issues [39,40]. In general, clinicians appear to have little to do with religious leaders and institutions [28]. The polarization of religion and spirituality into institutional and individual domains has jeopardized the understanding of personal affairs [41].

Possible reasons for the neglect are:

(a) It is less central (Bergin, 1991; "Politics of the Professorate," Shafranske)

(b) Outside the scope of scientific study [42]

(c) Should necessarily move away during an age of rational enlightenment $[43,44]$.

Health professionals often undervalue the role that religion has on patients' medical decisions. More recently, the Journal of Clinical Oncology published a survey of 100 patients with advanced lung cancer, their caregivers, and 257 medical oncologists attending the annual meeting of the American Society of Clinical Oncology. In this study, investigators asked participants to rank the importance of factors that might influence chemotherapy treatment decisions. Patients and family members have ranked faith in God as second most important factor but Oncologists ranked faith in God as least important [45-48].

Two basic assumptions have contributed to the neglect of research in this area:

(a) Spirituality cannot be studied scientifically

(b) Neither it Should be studied scientifically

\section{Developing attention}

At this time, spirituality is an emerging area of interest. Physicians may find that considering the spirituality may add a new dimension to clinical practice. Between the years 2000 and 2002, more than 1,100 additional articles, studies, and reviews involving religion, spirituality, and mental health appeared in psychology literature, compared with 101 articles between 1980 and 1982, suggesting a remarkable increase in attention paid to this area by scientific community. Recent initiatives to cover spirituality in medical education are discussed. Studies and surveys on the importance of incorporating spiritual discussions into medical care are reviewed $[49,50]$.

The Association of American Medical Colleges (AAMC) has cosponsored with National Institute for Healthcare Research to conduct four conferences on curricular development in spirituality and medicine. These conferences have been held annually since 1997.

A 1996 Gallup Poll showed that religion and expression of spirituality, plays a central role in the lives of many Americans. When asked, 95\% of persons surveyed espoused a belief in God, 57\% reported praying daily and $42 \%$ reported attending a worship service in the prior week. The American College of Physicians concluded that physicians should extend their approach to psychosocial, existential, or spiritual suffering [51,52].

\section{Barriers in spiritual training}

\section{Physician related}

For physicians, collecting spiritual information may be:

Time consuming

Something for which they are not trained

They may have difficulty managing, may project their views onto patients or question

Difficulty in identifying patients who want such a discussion

\section{Patient related}

An agnostic patient should not be told to engage in worship any more than a highly religious patient who should not be criticized for frequent church attendance. Proselytizing is never appropriate. In Lindgren \& Coursey's [53] study, 38\% of patients expressed discomfort with mentioning their spiritual or religious concerns to therapist.

\section{Research scarcity and inadequacies}

Systematic reviews of the empirical literature indicate that religion and spirituality are understudied. Weaver et al. [54,55] conducted a systematic review of research on religion and spirituality in articles published in several American Psychological Association journals between the years 1991-94. Weaver found $2.7 \%$ of the quantitative studies included a religion and spirituality variable. Published work lacks consistency, even among well-conducted studies. Idler and Kasl found effects of religious attendance on functional capacity in the elderly:

1) Measures of "religious involvement", an index of the "private, reflective" aspects of religion were not associated with any health outcome

2) Neither church attendance nor religious involvement was associated with lower mortality

Sloan et al. [56] characterized the empirical evidence linking religiousness to health is defective. Their criticisms included:

Misuse of statistics

Inappropriate designs

Inadequate sampling

Post hoc findings of studies not primarily about religiousness, and failure to exhibit those religious factors demonstrated a unique main effect (consistent with the unique variance approach)

\section{Recent additions}

In 1992, three medical schools offered courses on spirituality and health. In 2001, 75 of the 125 schools offered courses. At The George Washington University School of Medicine, spirituality is linked with the rest of the curriculum throughout the 4 years of medical school. Thus, when learning to take a history, students learn all aspects of life. Recently, 72 US medical schools have developed courses to teach students how to do spiritual assessments with patients, to integrate spiritual concerns into therapeutic plans, and when to refer patients to chaplains. 
Page 4 of 5

US medical schools increasingly offer courses in religion and spirituality. Recommendations of the Association of American Medical Colleges for a Curriculum on Spirituality Outcome goals are as follows:

- The ability to elicit a spiritual history

- An understanding that the spiritual dimension of people's lives is an avenue for compassionate care giving

- The ability to apply the understanding

- Knowledge of research data on the impact of spirituality on health and on health care outcomes

- An understanding of, and respect for, the role of clergy and other spiritual leaders

- An understanding of their own spirituality and how it can be nurtured as part of their professional growth, promotion of their wellbeing, and the basis of their calling as a physician

\section{Looking ahead; requirements for better research}

\section{Why it is needed?}

Healing, derived from German word for 'Whole', is more than a particular symptom. Culliford [57,58] relates it to structures of meaning, value and purpose that form the human experience.

A Survey by Ehman et al. [59] at the University of Pennsylvania showing $65 \%$ of patients in a pulmonary outpatient clinic noted that therapeutic alliance increases if physician's inquiry about spiritual beliefs addressed properly.

The American Journal of Psychiatry editorial (Andreasen) wrote it like, 'We must practice and preach the fact that psychiatrists are physicians to the soul as well as the body.' [60].

World Health Organization (1998) quotes health as 'a state of complete physical, mental and social well-being, not merely the absence of disease'. Mechanical treatment of objective findings in patients is no longer satisfactory. To shape more holistic view of health, Faith, hope and compassion should be integrated into healing process. Larson and Matthews [61] are building hope that the "wall of separation" between medicine and religion will be broken, and emphasize that "future is going to be prayer and Prozac".

\section{Conclusion}

According to the evidence based findings, mixed results of negative and positive associations are present, although data has showed positive linkage to great extent but considering past account of deficiencies, better methodology in future researches regarding religious practices and health findings are needed. Cross-sectional survey can be done among spiritually trained students and those who are not, in order to evaluate the differences (it is expected to make) in patient management and counseling. Proper training can diminish physician's related concerns like time consumption and poor spiritual assessment skills. More researches are needed on this ground for enhanced understanding of relationship and improvement of health system.

\section{References}

1. Puchalski CM (2001). Spirituality and health: the art of compassionate medicine. Hospital Physician 37: 30-36.

2. Lothane Z (1998) Freud's 1895 project. From mind to brain and back again. Ann N Y AcadSci 843: 43-65.

3. Droege, TA (1991) The faith factor in healing. Trinity Press.

4. Frank JD (1993) Persuasion and healing: A comparative study of psychotherapy. JHU Press.

5. Remen RN (1997) Kitchen Table Wisdom: Stories Thai Heal.

6. Koenig HG (2000) MSJAMA: religion, spirituality, and medicine: application to clinical practice. JAMA 284: 1708.

7. Martsolf DS, Mickley JR (1998) The concept of spirituality in nursing theories: differing world-views and extent of focus. J AdvNurs 27: 294-303.

8. James W (1902) The varieties of religious experience. New York:Random House.

9. Weiner, E. S., \& Simpson J (1991) The Compact Oxford English Dictionary.Oxford University Press, Oxford, 1422.

10. Wetzel MS, Eisenberg DM, Kaptchuk TJ (1998) Courses involving complementary and alternative medicine at US medical schools. JAMA 280: 784-787.

11. Anandarajah G, Hight E (2001) Spirituality and medical practice: using the HOPE questions as a practical tool for spiritual assessment. Am Fam Physician 63: 81-89.

12. Miller WR, Thoresen CE (2003) Spirituality, religion, and health. An emerging research field. Am Psychol 58: 24-35.

13. Ryff, CD, Singer B (1998) The contours of positive human health.Psychological inquiry, 9(1), 1-28.

14. Benson H, Beary JF, Carol MP (1974) The relaxation response.Psychiatry: Journal for the Study of Interpersonal Processes.

15. Larson DB, Milano MA (1995) Are religion and spirituality clinically relevant in health care? Mind/Body Medicine 1: 147-157.

16. Hill PC, Butler EM (1995) The role of religion in promoting physical health. Journal of Psychology and Christianity 14: 141-155

17. Strawbridge WJ, Cohen RD, Shema SJ, Kaplan GA (1997) Frequent attendance at religious services and mortality over 28 years. Am J Public Health 87: 957-961.

18. Strachan JG (1982). Alcoholism, Treatable Illness: An Honorable Approach to Man's Alcoholism Problem. Hazelden.

19. Benson H (1996). Timeless healing: The power and biology of belief Scribner, New York.

20. Hill PC, Pargament KI (2003) Advances in the conceptualization and measurement of religion and spirituality. Implications for physical and mental health research. Am Psychol 58: 64-74.

21. Koenig HG (2002) An 83-year-old woman with chronic illness and strong religious beliefs. JAMA 288: 487-493.

22. McCullough ME 1995) Prayer and health: Conceptual issues, research review, and research agenda. Journal of Psychology and Theology 23: 1529.

23. Duhl L (2001). Handbook of religion and health. Journal of Epidemiology and Community Health 55: 688.

24. Qidwai W, Tabassum R, Hanif R, Khan FH (2009). Belief in prayers and its role in healing among family practice patients visiting a teaching hospital in Karachi, Pakistan. Pakistan Journal of Medical Sciences 25: 182-189.

25. Emmons, R. A. (1999). Religion in the psychology of personality: An introduction. Journal of Personality, 67(6), 874-888.

26. Zinnbauer BJ, Pargament KI, Cole B, Rye MS, Butter EM, et al. (1997). Religion and spirituality: Unfuzzying the fuzzy. Journal for the scientific study of religion 549-564.

27. Baetz M, Griffin R, Bowen R, Marcoux G (2004) Spirituality and psychiatry in Canada: psychiatric practice compared with patient expectations. Can J Psychiatry 49: 265-271. 
Citation: Hena Jawaid (2014) Impact of Religion/Spirituality on Health: What are the Evidences?. J Psychiatry 17: 1000164. doi: $10.4172 / 1994-8220.1000164$

Page 5 of 5

28. Pirl WF, Roth AJ, Cotton SP, Levine EG, Fitzpatrick CM, et al. (2000) Exploring the relationships among spiritual well-being, quality of life and psychological adjustment in women with breast cancer. psychooncology 8(5) 1999, 429-438 Psychooncology 9: 89.

29. Freud S (2012) The future of an illusion. Broadview Press.

30. Ellis A (1980) Psychotherapy and atheistic values: a response to A. E. Bergin's "Psychotherapy and religious values". J Consult ClinPsychol 48: 635-639.

31. Pargament KI, Koenig HG, Tarakeshwar N, Hahn J (2001) Religious struggle as a predictor of mortality among medically ill elderly patients: a 2-year longitudinal study. Arch Intern Med 161: 1881-1885.

32. Galton F (1872) Statistical inquiries into the efficacy of prayer. Fortnightly Review 18: 125- 135.

33. Cobb M, Robshaw V (1998) The Spiritual Challenge of Health Care, Churchill Livingstone, New York.

34. Duckro PN, Magaletta PR (1994) The effect of prayer on physical health: Experimental evidence. J Relig Health 33: 211-219.

35. McCullough ME (1995) Prayer and health: Conceptual issues, research review, and research agenda. Journal of Psychology and Theology 23: 1529.

36. Poloma MM, Pendleton BF (1991) The effects of prayer and prayer experiences on measures of general well-being. Journal of Psychology and Theology 19:71-83

37. Silvestri GA, Knittig S, Zoller JS, Nietert PJ (2003) Importance of faith on medical decisions regarding cancer care. J ClinOncol 21: 1379-1382.

38. Skevington SM, Carse MS, Williams AC (2001) Validation of the WHOQOL-100: pain management improves quality of life for chronic pain patients. Clin J Pain 17: 264-275.

39. Bergin AE (1983) Religiosity and mental health: A critical reevaluation and meta-analysis. Professional psychology. Research and practice 14: 170 .

40. Shafranske EP, Malony HN (1990) Clinical psychologists' religious and spiritual orientations and their practice of psychotherapy. Psychotherapy 27: 72-78.

41. Wuthnow R (1998) After heaven: Spirituality in America since the 1950s. Univ of California Press.

42. Thomson KS (1996) The revival of experiments in prayer. American Scientist 84: 532-534.

43. Barbour IG (1990) Religion in an age of science. The Gifford Lectures 1989-1991 (Vol. 1). London: SCM.

44. Hill PC, Pargament KI, HoodRW, McCullough ME, Swyers JP, et al (2000) Conceptualizing religion and spirituality: Points of commonality, points of departure. Journal for the theory of social behaviour 30: 51-77.
45. Silvestri GA, Knittig S, Zoller JS, Nietert PJ (2003) Importance of faith on medical decisions regarding cancer care. J ClinOncol 21: 1379-1382.

46. Gallup GH (1996) Religion in America, 1996. Princeton Religion Research Center.

47. Lo B, Quill T, Tulsky J (1999) Discussing palliative care with patients. ACP-ASIM End-of-Life Care Consensus Panel. American College of Physicians-American Society of Internal Medicine. Ann Intern Med 130: 744-749.

48. Astrow AB, Puchalski CM, Sulmasy DP (2001) Religion, spirituality, and health care: social, ethical, and practical considerations. Am J Med 110: 283-287.

49. Ellis MR, Vinson DC, Ewigman B (1999) Addressing spiritual concerns of patients: family physicians' attitudes and practices. J FamPract 48 : 105-109.

50. Maugans TA, Wadland WC (1991) Religion and family medicine: a survey of physicians and patients. J FamPract 32: 210-213.

51. Oyama O, Koenig HG (1998) Religious beliefs and practices in family medicine. Arch Fam Med 7: 431-435.

52. Daaleman TP, Frey B (1999) Spiritual and religious beliefs and practices of family physicians: a national survey. J FamPract 48: 98-104.

53. Lindgren KN, Coursey RD (1995). Spirituality and serious mental illness: A two-part study. Psychiatric Rehabilitation Journal 18: 93-111.

54. Weaver AJ, Flannelly LT, Flannelly KJ, Koenig HG, Larson DB (1998) An analysis of research on religious and spiritual variables in three major mental health nursing journals, 1991-1995. Issues Ment Health Nurs 19: 263-276.

55. Idler EL, Kasl SV (1992) Religion, disability, depression, and the timing of death. Am J Sociol 97: 1052-1079.

56. Sloan RP, Bagiella E, Powell T (1999) Religion, spirituality, and medicine. Lancet 353: 664-667.

57. Puchalski CM, Larson DP, Lu FG (2001) Spirituality in psychiatry residency training programs. Int Rev Psych 13: 131-138.

58. Culliford L (2002) Spiritual care and psychiatric treatment: an introduction.Advances in Psychiatric Treatment 8: 249-258.

59. Ehman JW, Ott BB, Short TH, Ciampa RC, Hansen-Flaschen J (1999) Do patients want physicians to inquire about their spiritual or religious beliefs if they become gravely ill? Arch Intern Med 159: 1803-1806.

60. World Health Organization (1998) WHOQOL and Spirituality,Religiousness and Personal Beliefs: Report on WHOConsultation. Geneva: WHO.

61. Matthews DA, Larson DB (1997) Faith and medicine: reconciling the twin traditions of healing. Mind/Body Medicine 2: 3-6. 